\section{Systematic review of research and utilization of shallow geothermal energy in Croatia}

The Mining-Geology-Petroleum Engineering Bulletin UDC: 550.8

DOI: $10.17794 / \operatorname{rgn} .2018 .5 .4$

Review scientific paper

\author{
Marija Macenić'; Tomislav Kurevija' ${ }^{1}$; Kristina Strpić ${ }^{1}$ \\ ${ }^{1}$ Faculty of Mining, Geology and Petroleum Engineering; 10000 Zagreb, Croatia
}

\begin{abstract}
The utilization of shallow geothermal energy is well known in several European countries. Even though large parts of the Republic of Croatia show significant potential for its use, the installation of ground source heat pump systems (heat pump and heat exchangers) is slowly progressing. Therefore, a short overview of research published thus far concerning the utilization and assessments of shallow geothermal potential for Croatia was done. In Croatia, there is no agency or government department in charge of collecting and publishing data concerning installations of heat exchangers. Therefore, a study was done to collect the available data on installed closed-loop heat exchangers either from scientific research or from personal contacts with drilling companies. Based on the collected data, a map was produced that shows general locations of installed heat exchangers. From the obtained data of installed heat exchanger length, a first assessment of utilizing shallow geothermal potential in Croatia was given.
\end{abstract}

Keywords:

shallow geothermal energy, Croatia, heat exchangers.

\section{Introduction}

The exploration and use of shallow geothermal energy has been on the rise in the last decade in the Republic of Croatia. The technology has been known and widely used since the mid-20 $0^{\text {th }}$ century, and is used as heating and cooling energy, in both the residential and commercial sectors. Shallow geothermal energy is often defined as energy stored in the ground, up to a few hundred meters, depending on the definition. In general, shallow geothermal resources cannot be used directly for heating, as they require a heat pump system for heat distribution. According to Lund and Boyd (2015), in 2015 there was almost $50 \mathrm{GW}_{\mathrm{t}}$ capacity installed worldwide in the category of geothermal heat pumps, with over $325 \mathrm{PJ} / \mathrm{yr}$ energy utilization. In the same report, it is stated that in the Republic of Croatia, the total installed capacity of geothermal energy was $79.94 \mathrm{MW}_{\mathrm{t}}$ and energy usage of $684.49 \mathrm{TJ} / \mathrm{yr}$. It was estimated that geothermal or ground source heat pumps contribute with $4.50 \mathrm{MW}_{\mathrm{t}}$ of installed capacity and $42.50 \mathrm{TJ} / \mathrm{yr}$ of energy. It is not clear whether these amounts are from a utilization of all shallow source geothermal energy, by coupling heat exchangers and ground, ground-water and surface-water heat pumps, or from using only ground-source heat pump coupled systems. Since there is no regulatory agency or body to control the heat exchangers and heat pump installation,

Corresponding author: Tomislav Kurevija

e-mail address: tkurevi@rgn.hr it is difficult to say or estimate whether these amounts are correct and represent the real situation. To have a better understanding of the subject, general information on shallow geothermal systems is given. A search of literature on the subject of utilizing shallow ground geothermal energy showed that research has increased since 2008 and can be summarized to give an up-to-date overview of the subject in Croatia. Also, it was observed that there is a need to more accurately estimate the installed capacity and heating/cooling energy, obtained by using ground source heat pump systems. For that purpose, data on installed heat exchangers was collected and analyzed. Therefore, this paper reviews up-to-date research concerning shallow geothermal energy in the Republic of Croatia and gives an overview of the authors' research concerning installed ground heat exchangers.

\section{Shallow geothermal energy resource}

Geothermal energy is defined as energy stored in the form of heat in the subsurface of solid earth, according to Directive 2009/28/EC (2009). Depending on the depth at which it is extracted, it can be divided into deep or shallow geothermal resources. Rybach and Sanner (2000) stated that shallow geothermal resources are defined in several countries as a heat source found at less than $400 \mathrm{~m}$ of depth. Unlike deep geothermal, it only utilizes low-enthalpy heat, originating from a partially solar energy that was absorbed and stored in the subsur- 


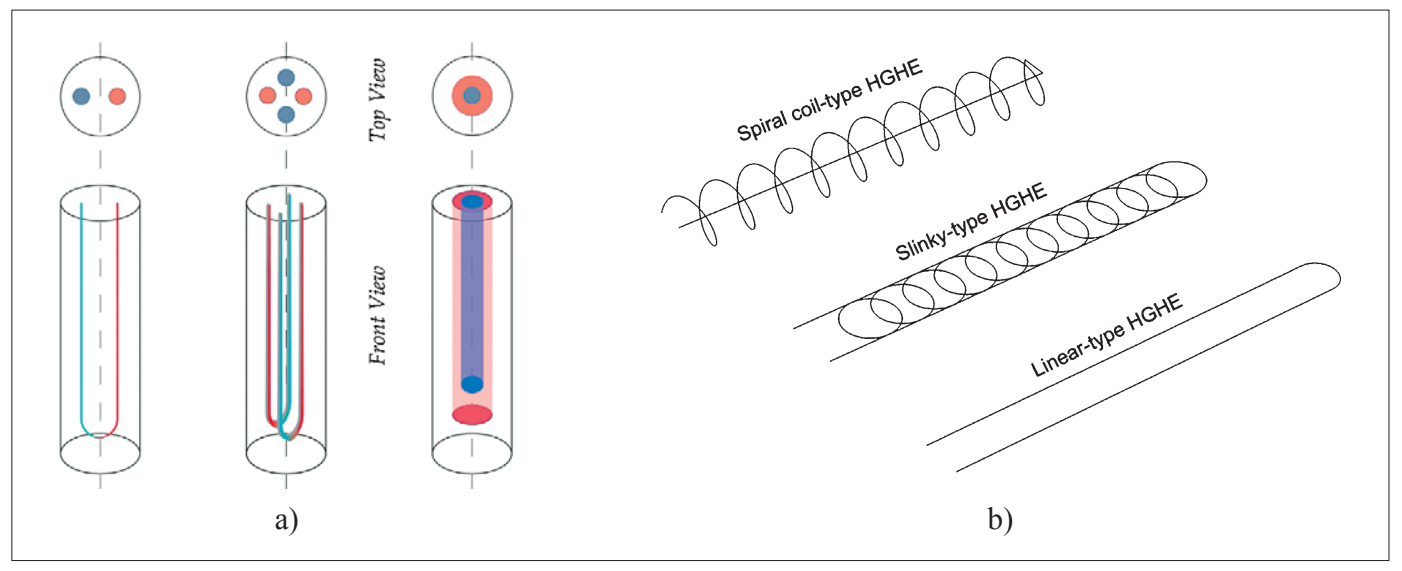

Figure 1. a) Schematics of borehole heat exchangers (Aresti et al., 2018)

b) Schematics of very shallow heat exchangers (Jeon et al., 2018)

face along with heat flow from deep-earth origins, according to Banks (2012) and Tinti et al. (2017). This shallow geothermal energy can be extracted by using open or closed heat pump systems. Open systems are represented by exploiting heat via boreholes or water wells directly from underground aquifers. It consists of two water wells or boreholes - one as a producer, and the other as an injector of used water.

Closed-loop systems are more diverse than open systems. According to Tinti et al. (2014), closed-loop systems usually circulate water-glycol mixtures in closed pipes of various configurations and inserted at various depths. A closed-loop system can then be divided into three main subcategories of borehole heat exchangers, very shallow heat exchangers and a closed-loop system that uses surface waters (lakes, ponds) as a heat source. Borehole heat exchangers (BHEs) are well investigated and used worldwide. There are three main configuration types of BHEs: single $\mathrm{U}(1 \mathrm{U})$, double $\mathrm{U}(2 \mathrm{U})$ and coaxial (CX) (see Figure 1a), which are usually inserted into the ground, from 50 to $200 \mathrm{~m}$ of depth (Tinti et al., 2014). Very shallow heat exchangers can generally be divided into horizontal ground collectors of various configurations, slinky, geothermal baskets or geothermal piles (see Figure 1b).

The technology that delivers heat to the object is a heat pump, whether it uses an open or closed heat exchange system. The heat pump extracts or rejects the heat from the heat source via heat exchangers. In the case of shallow geothermal energy, the heat source is either ground, underground water or surface waters such as ponds or lakes (see Figure 2). The principle of heat pump operation is based on a reverse Carnot cycle (Sarbu and Sebarchievici, 2014). Borehole heat exchangers and ground source heat pumps form a system that uses the almost constant temperature of the ground throughout the year, in order to heat or cool residential or commercial buildings (Javed et al., 2011). In addition, such systems can be used to prepare domestic hot water (DHW) for users. During the heating period, the ground is a heat source, while during the cooling period, by re- jecting the excess heat from buildings, the ground acts as a heat sink (Sanner et al., 2003). The working fluid, usually a water or antifreeze mixture, is being circulated through the closed heat exchanger when a ground source system is used. The working fluid transfers heat from the ground to the evaporator of the heat pump, and vice versa when the pump is operating in the cooling regime. The coefficient of performance, or COP, is defined as the ratio of obtained useful heating energy and electric consumption of the heat pump (Sanner et al., 2003). In other words, the COP shows the efficiency of the heat pump system. The same study reports that the COP depends on the temperature of the working fluid at the inlet to the heat pump or rather on thermogeological and hydraulic parameters, technical parameters of the heat exchangers themselves, heating/cooling load and the type of the heating system installed in the building (underfloor heating system, fan-coils, etc.). The thermal response test (TRT) is a well-known method used for determining thermogeological properties of the ground. Classic TRT is used to determine undisturbed ground temperature as well as thermal conductivity. The procedure of performing classic TRT and method to evaluate said properties is detailed in the work of Gehlin (2002). Even though the utilization of deep geothermal energy is more favorable due to higher temperatures, it is not easily available for direct use. It is used in countries and regions with favorable geothermal gradients and heat flows. The initial costs are usually very high, mainly because of high drilling costs. In comparison, shallow geothermal energy is available around the world and has a lower initial cost. However, when compared to classic district or domestic heating systems, they show a higher initial cost (Molavi and McDaniel, 2016). However, the same study showed that the cost of electricity used for operating the heat pump is lower than the cost of fuel oil in a classic heating system, which can lead to economical savings. A study showed that ground source heat pumps can be used in heating not only, new, low energy buildings, but also in older, historical buildings (Pacchiega and Fausti, 2017). 


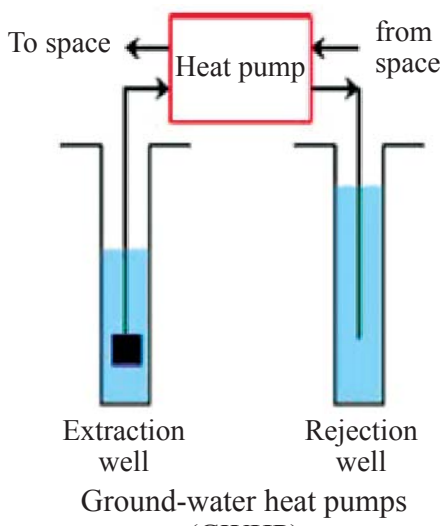

(GWHP)

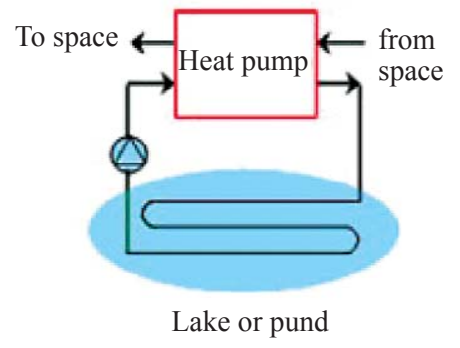

Surface-water heat pumps (SWHP)

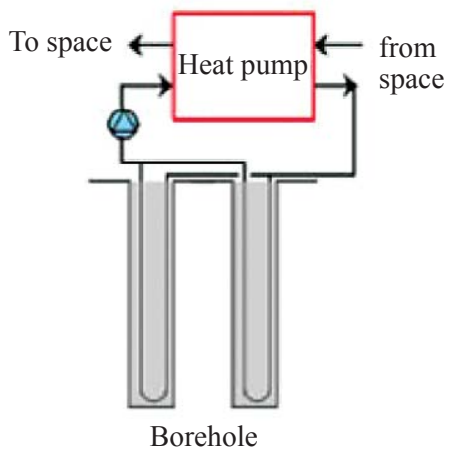

Ground-coupled heat pumps (GCHP)

Figure 2. Schematics of various heat source heat pump systems (Sarbu and Sebarchievici, 2014)

Since there is a rise in installed geothermal heat exchangers and ground source heat pump systems and a rise in research concerning shallow geothermal energy in Croatia, a review of published research for the country was done. Data on installed heat exchangers was collected, using up-to-date research as well as contacts with companies which deal with the installation of such systems.

\section{Overview of research on shallow geothermal energy in Croatia}

The most important thermogeological properties are geothermal gradient, thermal conductivity, thermal diffusivity and heat capacity of the ground. Accurate determination of these parameters helps with proper sizing and design of the whole system - heat exchanger and ground source heat pump.

The Republic of Croatia has a short history of using shallow geothermal energy, when compared to other European countries, regardless of its good geothermal potential. The first person to determine the geothermal potential of Croatia was Jelić within his doctoral thesis, where evaluation of thermal characterization was given for the Sava and Drava sub-basins, which are part of a larger Croatian Pannonian Basin System (Jelić, 1979). By analyzing data obtained for over 100 deep boreholes, drilled as survey, oil, gas or geothermal wells, correlations for determining geothermal properties (thermal conductivity, geothermal gradient) of rock up to 2000 meters were obtained, for each of the sub-basins. Correlations for determining rock density and heat capacity were also determined. With thermal conductivity, rock density and heat capacity, thermal diffusivity can be determined, which is an important geothermal parameter since it shows the rate of heat transfer.

Jelić and Lukačević (1989) published the results of extensive research on geophysical exploration and testing on rock samples to determine thermal conductivity for the area of Zagreb. Further exploration of the subject led to the publishing of maps of geothermal gradient and heat flow for all of Croatia in 1997 (Jelić and Kevrić, 1997). The values of geothermal gradient and heat flow showed that Croatia can be divided into two distinct regions: Dinarides with Adriatic coastline and Pannonian Basin. For the region of the Dinarides with Adriatic coastline, the authors determined that the values of geothermal gradient are in the range of 0.01 up to 0.025 ${ }^{\circ} \mathrm{C} / \mathrm{m}$ with a mean value of $0.018^{\circ} \mathrm{C} / \mathrm{m}$. The heat flow in this region was determined at $0.029 \mathrm{~W} / \mathrm{m}^{2}$ (see Figure 3a). In the region of the Pannonian Basin, the geothermal gradient was determined to be in the range of 0.04 to $0.07{ }^{\circ} \mathrm{C} / \mathrm{m}$, with a mean heat flow of $0.076 \mathrm{~W} / \mathrm{m}^{2}$ (see Figure 3a). The Croatian Pannonian Basin System (CPBS) is a part of the larger Pannonian Basin System (PBS). The CPBS is divided into four main sub-basins - Sava, Drava, Mura, and Slavonija-Srijem (see Figure 3b). The first three are named after the main rivers flowing through the respective areas. The Sava sub-basin shows a mean geothermal gradient of $0.048{ }^{\circ} \mathrm{C} / \mathrm{m}$ and mean heat flow of $0.067 \mathrm{~W} / \mathrm{m}^{2}$. The Drava sub-basin showed values somewhat higher than the Sava sub-basin, with a mean geothermal gradient of $0.051{ }^{\circ} \mathrm{C} / \mathrm{m}$ and a mean heat flow of $0.082 \mathrm{~W} / \mathrm{m}^{2}$. Due to low resolution, the map of geothermal gradients was later digitally reproduced, with the same data (Kurevija et al., 2014).

There are two distinct geothermal regions as seen in Figure 3a, based on geothermal gradient values. The differences in heat flow, and consequently geothermal gradient are most likely to be due to the shallow position of Mohorovičić discontinuity in the Pannonian basin, at around $30 \mathrm{~km}$. In the region of the Dinarides, the Mohorovičić discontinuity is at around the depth of 50 $\mathrm{km}$. According to Kurevija (2008), there was no significant use of shallow geothermal energy via heat pumps by 2008 in Croatia. In the same paper, techno-economic analysis of using such a system for heating and cooling was presented for a building in Zagreb with a review of cost-effectiveness for a specified area, which showed potential in utilizing ground source heat pumps.

Ruševljan et al. (2009) stated that proper design of shallow geothermal systems is usually based on com- 


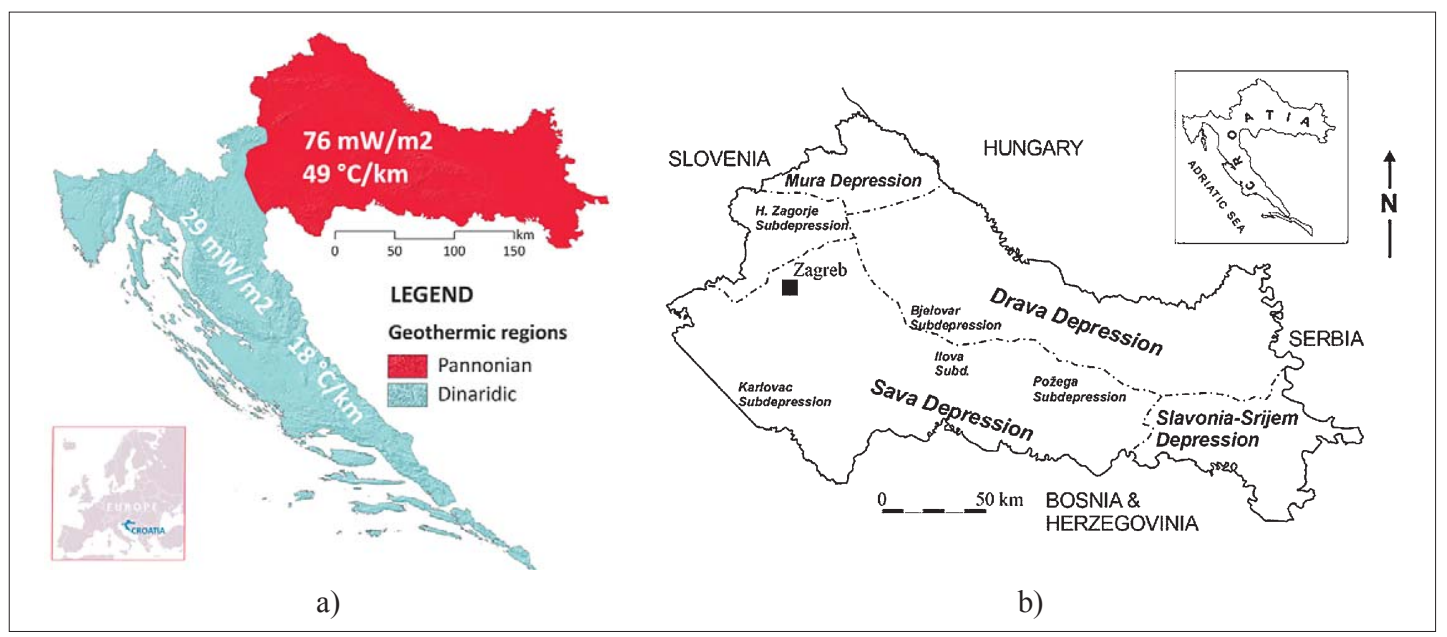

Figure 3. a) Two distinct geothermal regions of Croatia (Borović et al., 2016) b) Schematic of four main sub-basins of the Croatian Pannonian Basin (Malvić, 2016)

plex mathematical simulations that have to be performed not only for peak building loads but also for building loads that are calculated throughout the whole year. For this reason, the building loads have to be analyzed in more detail than for sizing of a conventional system. Designers of heat pump systems coupled to the BHE should also take into account the long-term temperature changes in the ground surrounding the borehole, which would influence the overall efficiency of the system during its life cycle.

One of the first scientific research studies on standard double-loop borehole heat exchangers was carried out by Soldo and Ruševljan (Ruševljan et al., 2009; Soldo et al., 2010) at the Faculty of Mechanical Engineering and Naval Architecture in Zagreb. For research purposes, the first borehole of $100 \mathrm{~m}$ was drilled and a $2 \mathrm{U}$ (double $\mathrm{U}$ heat exchanger) heat exchanger was inserted, along with the thermocouples for each $10 \mathrm{~m}$ of depth. Also, during this research, the first prototype of Thermal Response Test (TRT) equipment was constructed by the same authors. Data showed that the temperature at $100 \mathrm{~m}$ in the city of Zagreb is $15.2^{\circ} \mathrm{C}$ and that the average temperature during test circulation is $13.5^{\circ} \mathrm{C}$.

The first commercial testing with TRT equipment was conducted during soil investigation works prior to construction of the IKEA store in Zagreb. Based on this investigation, Soldo et al. (2011) gave the first data about thermal conductivity in the city of Zagreb, which was $1.7 \mathrm{~W} / \mathrm{m}^{\circ} \mathrm{C}$. These results, as well as those obtained from the test borehole at their Faculty, were published in numerous domestic and international conferences, promoting the development of shallow geothermal research in Croatia (Soldo et al. 2010, 2011, 2015).

Based on the research of Jelić (1979), Jelić and Lukačević (1989) and Jelić and Kevrić (1997), Kurevija (2010) concluded that mean thermal ground conductivity up to $100 \mathrm{~m}$ will vary between 1.5 and $1.8 \mathrm{~W} / \mathrm{m}$ ${ }^{\circ} \mathrm{C}$ for the northern part of Croatia. In the same doctoral thesis (Kurevija, 2010), a techno-economic evaluation of shallow geothermal potential in Croatia was carried out. Analysis showed that areas of significant potential are continental parts (mainly the Pannonian Basin) and the Adriatic coastline, with the Dinarides regions showing lower potential for implementing ground source heat pump systems.

Besides thermal conductivity and geothermal gradient, the undisturbed ground temperature is an important element when assessing shallow geothermal resources. Undisturbed ground temperature is defined as a ground temperature at a depth where there is no influence of climatic changes and solar radiation on ground temperature. Undisturbed ground temperature can be determined while performing a Thermal Response Test (TRT) and is an important parameter when sizing the heat exchanger system (i.e. determining its length). A Thermal Response Test is a method for determining ground thermal properties. This method consists of circulating heated fluid through the heat exchanger with a pump, thus rejecting the heat in the ground via TRT equipment. When performing the test, the heat is rejected to the ground and the temperature response of the circulating fluid at the inlet and outlet of the exchanger is logged. Heat rejection rates are set with turning the heaters on and off. Based on the heat rejection rate, the heat extraction rate can be determined since they are mirror values. From the collected data of temperature response, thermal conductivity and resistance can be determined (Gehlin, 2002). According to ASHRAE (2007) the testing period should last between 36 and 48 hours, for results to be representative. Javed et al. (2011) report that there are a few recommendations concerning the time to perform TRT, which span from less than 24 hours up to 60 hours. It was recommended, in the same study, that the thermal response test should have a duration of a minimum of 50 hours, in order to have more accurate determination of thermogeological properties. 
When seasonal ground temperature deviations are monitored, Kurevija and Vulin (2010) determined three main regions of Croatia, based on the analysis of ground temperatures obtained from various regional meteorological stations. Analysis showed that in Northern Croatia, a mean undisturbed temperature of $13.1^{\circ} \mathrm{C}$ can be found at a depth of $10.5 \mathrm{~m}$. For the region of Lika and Gorski Kotar, it was found that an undisturbed ground temperature of $11.9^{\circ} \mathrm{C}$ occurs at a depth of $11.4 \mathrm{~m}$. In the third region, the Adriatic, due to large climate diversities, the mean value of undisturbed temperature at a specific depth could not be uniformly determined. However, data is available for four cities which represent a larger city area. For Rijeka, the undisturbed ground temperature is $14.1^{\circ} \mathrm{C}$ (at $6.6 \mathrm{~m}$ ), for Zadar it is $17.0^{\circ} \mathrm{C}(11.1 \mathrm{~m})$, for Split $14.7^{\circ} \mathrm{C}$ (at $14.8 \mathrm{~m}$ ) and for Dubrovnik $17.4^{\circ} \mathrm{C}$ (at $12.3 \mathrm{~m}$ ).

When it comes to the sizing of a heat exchanger system, Kurevija et al. (2012) showed the influence of different geometric arrays, the spacing of adjacent boreholes and thermal interference on determining the required borehole length. The analysis showed discrepancies in calculated borehole length when using two methods describing heat transfer - simple line source and cylindrical source. The discrepancies were smaller in cases of larger spacing between boreholes in a given borehole array.

Kurevija et al. (2014) analyzed the influence of geothermal gradient on sizing borehole heat exchangers for the area of Zagreb, since the ground temperature will depend on the geothermal gradient after the depth of undisturbed ground temperature. It was found that in the regions where geothermal gradients are higher than average, they can have a significant impact on sizing the length of borehole heat exchangers.

As part of the IPA (Instrument for Pre-Accession Assistance) project, titled "Research and the promotion of the use of shallow geothermal potential in Croatia (Grant no. IPA2007/HR/16IPO/001-040506), 8 borehole heat exchangers were installed in the area of the Pannonian basin and the Dinarides. The project is also referred to as GeoThermalMapping. The purpose was to assess the potential for use of ground source heat pumps in representative geological formations in Croatia. The project was carried out by the Faculty of Mechanical Engineering and Naval Architecture, in cooperation with the Croatian Geological Survey.

In order to determine undisturbed ground temperatures, an improved method of TRT was applied for measuring (Soldo et al., 2016). The method is called a distributed thermal response test (DTRT), and it measures the temperature of the circulating working fluid by optic fiber cable inside the BHEs. By applying the DTRT, vertical distribution of thermal conductivity and borehole thermal resistance are determined along the length of BHE. The results obtained by DTRT were compared with those of TRT and direct measurements of sediments for a $100 \mathrm{~m}$ double-U pipe heat exchanger in Osijek. The results showed good agreement between DRTR and TRT measured values. However, there were some discrepancies when compared to the direct measurement of thermal properties. It was concluded that for a large-scale heat pump and for the location, application of the thermal response test is recommended.

Boban et al. (2015) showed that use of a fiber-optic cable for distributed temperature sensing allows for the determination of the vertical distribution of thermal properties as the main output data. DTRT consists of three phases. In the first phase, temperature is measured with no fluid circulation. For the next 48 hours, fluid is circulated with imposed constant heat flux and in the last phase, thermal recovery of the ground is observed. While the second phase allows for the determination of thermal properties, the last phase gives an indication about heat transport in ground layers. Thermal properties for one location are presented, together with the influence of the groundwater flow on the conventional thermal response test and the effective values of the thermal properties is obtained.

Later, Soldo et al. (2016) published results of measurement on all 8 locations with DTRT. On 8 different sites, double-U pipe heat exchangers were installed, with a depth of 100 or $130 \mathrm{~m}$. The results of measuring temperature response showed that in the Pannonian Basin, characterized by various sediments, thermal conductivity is in the range of 1.62 to $2.1 \mathrm{~W} / \mathrm{m}{ }^{\circ} \mathrm{C}$. The Dinarides locations showed larger variability in results, in the range of 2.01 to $3.19 \mathrm{~W} / \mathrm{m}^{\circ} \mathrm{C}$, and is characterized dominantly with carbonate rocks. Based on the results, it was concluded that the coastline, as part of the Dinarides region, shows potential for utilizing shallow geothermal energy. BHEs located in the mountain region of the Dinarides showed lower values of undisturbed ground temperature. These findings are in accordance with the results of Kurevija and Vulin (2010).

Besides GeoThermalMapping, there are a few other projects in Croatia that deal with the utilization and monitoring of shallow geothermal energy. One of them was LEGEND (Low Enthalpy Geothermal Energy) which covered countries of the Adriatic area (Tinti et al., 2016). As a partner, two regional energetic agencies were involved - IRENA (Istrian Regional Energy Agency) and DUNEA (Regional Development Agency of Dubrovnik Neretva County). The project lasted from 2012 to 2015. Through IRENA, two public buildings in Labin, Istria were set with vertical borehole heat exchangers with corresponding heat pumps. DUNEA was involved in the project by installing heat baskets in one public building in Opuzen, Dubrovnik Neretva County. A remote monitoring system was installed at every location. The entire project showed a favorable potential of using shallow geothermal energy for the Adriatic area (Tinti et al., 2016), which is in accordance with previous research of the Adriatic coastline in Croatia. 
Another EU funded project that deals with the investigation of shallow geothermal potential is MUSE Managing Urban Shallow Geothermal Energy (http:// geoera.eu/projects/muse/). The project is focused on investigating shallow resources in European urban areas. Croatian Geological Survey is a representative partner for Croatia. The MUSE project is currently running, with the end date in 2021.

Besides thermogeological parameters of the ground (i.e. undisturbed ground temperature, thermal conductivity, and thermal diffusivity) and geometry parameters of the heat exchangers, grout properties are also important parameters when designing ground source heat pump systems. The research to determine the influence of various grouts was conducted in the area of Zagreb with, then novel, steady-state thermal response step testing (SS-TRST) (Kurevija et al., 2017). The results showed that in a mediocre thermal conductivity environment, there is no techno-economic benefit of using thermally enhanced grout. The novel method of SS-TRST consists of performing extended TRT, with a series of fall-off tests, carried out with lowering the heat power of the heater, until steady-state is achieved for each of the fall-off steps. The analysis was done for three consecutive fall-off tests for a real project of installed heat exchangers in the area of Zagreb. The results showed good agreement between the obtained values from fall-off tests and values obtained by extending the line from the response of the first step by using a line source linear trend equation. This showed that the usually long performing TRT could be shortened by using a series of fall-off tests.

In order to determine the hydraulic and thermogeological design difference of double- $U$ and coaxial heat exchangers, an extended thermal response test was carried out on two different locations in the area of Zagreb (Kurevija and Strpić, 2018). It was stated that there is a growing trend of installing inclined multiple coaxial heat exchangers, with an average depth of 40-50 m for each borehole. Hydraulic nomograms for both designs of BHE were presented, with respect to different glycol mixtures. From the hydraulic and thermodynamic standpoint, it was shown that double-U exchangers consume less electrical energy for circulation pumps and therefore are more favorable. It was concluded that coaxial heat exchangers are still viable to use in cases where there is a relatively small area for installation around an object. Two different coaxial pipe pair was used to determine values of thermal borehole resistance $-63^{17} / 40^{11}$ and $63^{11} / 32^{11}$ (where numbers designate pipe properties: diameter ${ }^{\mathrm{SDR}}$ ). The results showed that the coaxial pair $63^{17} / 40^{11}$ has an advantage compared to $63^{11} / 32^{11}$ pipes, due to lower thermal borehole resistance. For a coaxial heat exchanger to have more similar hydraulic and thermodynamic properties to double-U pipes, the working fluid mixture must have a lower content of glycol. Analysis of novel SS-TRST showed that in the same geologi- cal setting, the heat extraction rate for a coaxial heat exchanger is around $20 \%$ less than for a double-U vertical heat exchanger (Kurevija and Strpić, 2018). It was concluded that the lower heat exchange rate in a coaxial system was due to higher equivalent borehole thermal resistance. a novel approach in determining the starting period of semi-steady state heat transfer was applied, in order to determine the timeframe when the temperature change is a linear function of the logarithm of time. This approach is similar to the derivation curve method used for well testing analysis in the petroleum industry.

Further research was conducted on three different coaxial heat exchangers in the area of Zagreb with the application of the classic thermal response test and steadystate thermal response step testing (Kurevija et al., 2018). The analysis was done with respect to active and passive cooling. Classic TRT was done to determine thermogeological properties of each location as well as values of thermal borehole resistance. Analysis of SSTRST was used for determining heat rejection rates for active and passive cooling. It was concluded that data obtained from SS-TRST can be used in proper sizing of the borehole heat exchangers. The analysis showed that coaxial BHEs are not adequate for passive cooling systems.

Borović et al. (2018) investigated the possible installation of ground- and water-source heat pumps in karst terrains with discussing case studies from Croatia. It was determined that rock thermal conductivities are favorable for ground heat pump utilization and that wells with high enough yield and stable seawater or groundwater temperatures for water source heat pump utilization can be designed in appropriate structural settings. The advantages and disadvantages of the utilized methodology have been pointed out, as well as methods which should prove useful in the future. Hydrogeological, geotechnical and thermal risks expected during the drilling, installation and operational phases have also been identified. Presented case studies have given insight into the heat pump installation options and conditions in the Croatian part of the Dinarides, but can be useful to other researchers and engineers both in the Dinarides and in similar karst regions.

Research on undisturbed ground properties was done by performing a TR test with two different heat injection rates and by logging temperature profiles of the borehole wall at different depths of the double-U heat exchanger, in the area of Zagreb (Boban et al., 2018). Temperature response on the different radius from the borehole was also logged. The results showed that the falloff method is useful in evaluating variations of thermal properties with time. The analysis also showed that if higher heat flow rates are used while performing TRT, it can minimize the influence of heterogeneous environment as well as groundwater.

Another approach well known in the petroleum industry, called the Horner method, was applied in analyz- 


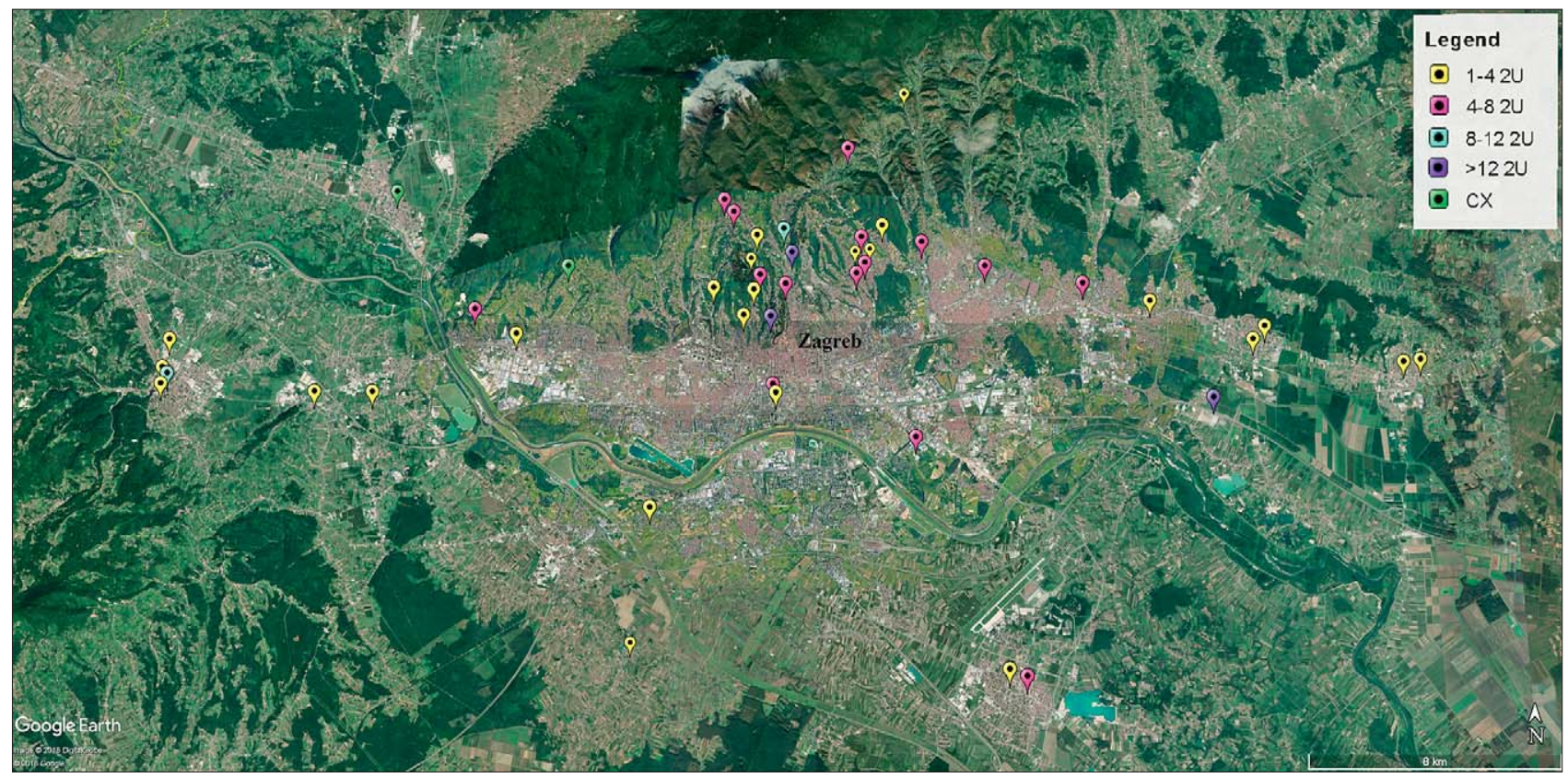

Figure 4. Installations of ground source heat exchanger systems in the wider area of Zagreb (available at DOI: 10.13140/RG.2.2.14374.57924)

ing the results of the thermal response test with regard to falloff temperature, logged after the heater is turned off (Kurevija et al., 2018). This is possible due to the same analogy of solving diffusivity equations for radial fluid flow and heat flow. In this case, the time for heat rejection to the ground was set to 96 hours. The recovery time, or falloff period, also lasted 96 hours. Two possible flow directions were set for a coaxial heat exchanger in Zagreb, with five different heat rejection rates. The cumulative measuring time was 2000 hours. With the obtained results, a recommendation was made to perform a falloff test, whenever it is possible. This is due to the observation that by analyzing the falloff thermal test temperature response, it is possible to determine thermal conductivity more accurately.

\section{Utilization of shallow geothermal energy in Croatia}

In the Republic of Croatia, there is no legislative or regulatory office that deals with the installation of ground heat exchangers. When it comes to the legislature, they are defined as simple construction objects/installation and they do not require any form of permit, as stated in the Ordinance on Simple and Other Buildings and Works (NN 112/17). This can be considered as an advantage for the investors. Since there is no unified legislature at a government level, there is no project data monitoring of installed ground heat pump systems. This can pose an inconvenience when it comes to setting up a dimensioning standard and project quality certification. A quality database with thermo-technical properties of existing systems can be of great use to geothermal and mechanical engineering designers for future installations. Therefore, a list of installed systems was formed considering the available literature, as well as through personal contact with drilling companies providing shallow geothermal installation service. Not every installed system is on the map, since not every company was willing to share their information, but a vast majority was available. Based on this data, a map was formed in the Google Earth ${ }^{\mathrm{TM}}$ application, with approximate locations of installed systems in Croatia. Since the majority of installations are disclosed private investors, the locations are pinpointed approximately in the area. Each pin has a short description of configuration and length of installed heat exchangers, thermal conductivity, where available, and the year of the installation. It can be seen that the installation of the double- $U$ heat exchanger prevails among others. There are only a few coaxial systems, a couple of heat baskets and one geothermal piles system installed. Considering the configuration and construction of the geothermal piles, when observing yield and circulation, they can be considered as shallow double-U (2U) heat exchangers. The map shows that most of the installations are concentrated in the wider area of Zagreb. Therefore, Figure 4 shows the said area, as presenting the entire map would not be clear when displaying every installation. The map and location descriptions for all of Croatia and each system were done in Google Earth Pro ${ }^{\mathrm{TM}}$ and the results are freely available at ResearchGate $^{\text {TM }}$ DOI: 10.13140/RG.2.2.14374.57924.

Collected data showed that the overall length of installed closed-loop heat exchangers is $44615 \mathrm{~m}$. Of the overall length, $3280 \mathrm{~m}$ is the length of installed coaxial borehole heat exchangers. The overall length of double- 
Table 1. Specification of installed systems in the heating regime

\begin{tabular}{|l|c|c|c|c|c|c|c|}
\hline \multicolumn{7}{|c|}{ Heating regime, Entering source temperature $0^{\circ} \mathrm{C}$} \\
\hline $\begin{array}{l}\mathrm{COP} \\
4.5\end{array}$ & $\begin{array}{c}\text { Calculated heat power } \\
\text { per length W/m }\end{array}$ & $\begin{array}{c}\text { Heat exchanger } \\
\text { length, } \mathrm{m}\end{array}$ & $\begin{array}{c}\text { Working } \\
\text { hours, } \mathrm{h}^{*}\end{array}$ & $\mathrm{~kW}_{\mathrm{t}}$ geo. & $\begin{array}{c}\sum \text { instal. } \\
\mathrm{kW}_{\mathrm{t}}\end{array}$ & $\begin{array}{c}\mathrm{GWh}_{\mathrm{t}} \\
\text { geothermal }\end{array}$ & $\mathrm{GWh}_{\mathrm{t}}$ geo+el. \\
\hline $2 \mathrm{U}$ & 53.2 & 41335 & 1200 & 2199 & 2817 & 2.64 & 3.39 \\
\hline $\mathrm{CX}$ & 32.2 & 3280 & 1200 & 106 & 235 & 0.13 & 0.16 \\
\hline$\sum$ & & 44615 & & 2305 & 2963 & 2.77 & 3.56 \\
\hline
\end{tabular}

* yearly equivalent of working hours of ground source heat pump for heating regime, at full power

Table 2. Specification of installed systems in the cooling regime

\begin{tabular}{|l|c|c|c|c|c|c|c|}
\hline \multicolumn{7}{|c|}{ Cooling regime, Entering source temperature $25^{\circ} \mathrm{C}$} \\
\hline $\begin{array}{l}\text { EER } \\
5.5\end{array}$ & $\begin{array}{c}\text { Calculated heat power } \\
\text { per length W/m }\end{array}$ & $\begin{array}{c}\text { Heat exchanger } \\
\text { length, } \mathrm{m}\end{array}$ & $\begin{array}{c}\text { Working } \\
\text { hours, } \mathrm{h}^{*}\end{array}$ & $\mathrm{~kW}_{\mathrm{t}}$ geo. & $\begin{array}{c}\sum \text { instal. } \\
\mathrm{kW}_{\mathrm{t}}\end{array}$ & $\begin{array}{c}\mathrm{GWh}_{\mathrm{t}} \\
\text { geothermal }\end{array}$ & $\mathrm{GWh}_{\mathrm{t}}$ geo+el. \\
\hline $2 \mathrm{U}$ & 42.1 & 41335 & 400 & 1741 & 1472 & 0.70 & 0.85 \\
\hline $\mathrm{CX}$ & 24.9 & 3280 & 400 & 82 & 61,9 & 0.03 & 0.04 \\
\hline$\sum$ & & 44615 & & 1822 & 1542 & 0.73 & 0.89 \\
\hline
\end{tabular}

* yearly equivalent of working hours of ground source heat pump for cooling regime, at full power

$\mathrm{U}$ heat exchangers is $41335 \mathrm{~m}$. By determining mean values of heating/cooling power for each of the systems, a simple estimation of installed capacity and heating/ cooling energy was done, considering typical efficiency parameters (such as coefficient of performance - COP). The results are shown in Table 1 and Table 2, for heating and cooling regimes respectively. In the heating regime, electrical energy required for heat pump operation (or rather the compressor) is considered as a useful heating effect, which is delivered to a building (Banks, 2012). Therefore, in Table 1, it can be seen that it is added to the installed capacity and energy (labeled as " $\sum$ install." and "geo+el."). The opposite is valid for the cooling regime, where electricity used for the operation of the compressor is considered as a waste heat that has to be disposed of (Banks, 2012). In Table 2, this is shown as a decrease in installed geothermal power and energy. It is estimated that total heating and cooling energy obtained by using shallow geothermal energy is 4.45 $\mathrm{GWh}_{\mathrm{t}}$ while the installed capacity for heating and cooling, when observing only the geothermal source, amounts to $4.13 \mathrm{MW}_{\mathrm{t}}$, while the total installed capacity (when accounting for the compressor) is $4.54 \mathrm{MW}_{\mathrm{t}}$.

\section{Conclusions}

Shallow geothermal energy shows significant potential for utilization in Croatia. Previous research showed that the continental region and region of the Adriatic coastline have a great perspective for utilization. In the continental region, this is due to favorable geothermal gradients and the geological setting. Even though along the Adriatic coastline the geothermal gradient shows low to moderate values, a favorable shallow geothermal potential is present because of the geological setting, which shows that rocks are mostly carbonates, with favorable thermal conductivity. The classic thermal response test (TRT) was performed to determine undisturbed ground temperature and thermal conductivity - important parameters for the sizing of the borehole array and the results were reported in several papers. A review of up-todate research shows that there are new findings concerning methods of determining thermogeological properties (such as SS-TRST or DTRT), which can be used to design optimal systems, applicable everywhere, not only in Croatia. In a European union funded project (GeoThermalMapping), the distributed thermal response test (DTRT) was performed on at least 8 borehole heat exchangers, throughout Croatia, to determine undisturbed ground temperature along the length of the borehole, as well as thermal conductivity at different geological settings. With a novel SS-TRST method, or extended thermal response test, heat rejection rates and borehole thermal resistance can be determined. With that, a better sizing of the borehole heat exchangers is possible. By using the Horner method, well known in petroleum engineering, analysis of falloff temperature can give more accurate values of thermal conductivity. The overview of research shows a good scientific basis for use in future specific projects of using shallow geothermal in heating and/or cooling commercial and residential buildings/objects. In order to give a more accurate estimation on the installed capacity and heating/cooling energy, data on installed heat exchanger systems was collected and is shown on a map, which is available online. Based on typical efficiency parameters and the length of the installed heat exchangers, total heating and cooling energy and installed capacity for shallow ground source geothermal systems was determined. Collected data of installed heat exchangers can serve as a starting point for future references when assessing exploitation of shallow geothermal energy. 


\section{References}

Aresti, L., Christodoulides, P. and Florides, G. (2018): A review of the design aspects of ground heat exchangers. Renewable and Sustainable Energy Reviews, 92, 757-773.

ASHRAE (2007): ASHRAE Handbook - HVAC Applications. American Society of Heating, Refrigerating and Air Conditioning Engineers, Inc. Atlanta, USA.

Banks, D. (2012): An introduction to thermogeology: ground source heating and cooling. John Wiley \& Sons. 526 p.

Boban, L., Lepoša, L., Soldo, V. and Grozdek, M. (2015): Influence of groundwater flow on implementation of distributed thermal response test. In: 24th IIR International Congress of Refrigeration (ICR2015), 16-22.08.2015., Yokohoma.

Boban, L., Soldo, V., Stošić, J., Filipović, E. and Tremac, F. (2018): Ground Thermal Response and Recovery after Heat Injection: Experimental Investigation. Transactions of FAMENA, 42, SI-1, 39-50.

Borović, S., Marković, T., Larva, O., Brkić, Ž. and Mraz, V. (2016): Mineral and Thermal Waters in the Croatian Part of the Pannonian Basin. In: Papić, P. (ed.): Mineral and Thermal Waters of Southeastern Europe - Springer, 31-45, $174 \mathrm{p}$.

Borović, S., Terzić, J. and Urumović, K. (2018): Installation of ground-and water-source heat pumps in karst terrains (case studies from Croatia). In KARST 2018 Expect the Unexpected.

Directive 2009/28/EC of the European Parliament and of the Council of 23 April 2009 on the promotion of the use of energy from renewable sources and amending and subsequently repealing Directives 2001/77/EC and 2003/30/EC.

Gehlin, S. (2002): Thermal Response test: Method development and evaluation. Ph.D. thesis, Lulea University of Technology.

Javed, S., Spitler, J. D. and Fahlén, P. (2011): An experimental investigation of the accuracy of thermal response tests used to measure ground thermal properties. ASHRAE Transactions, 117, 1, 13-21.

Jelić, K. (1979): Termičke osobine sedimentacionog kompleksa jugozapadnog dijela Panonskog bazena (Thermic properties of sedimentation complex of southwest region of Pannonian Basin). Ph.D. thesis, University of Zagreb, Faculty of mining, geology and petroleum engineering.

Jelić, K. and Lukačević, M. (1989): Solar Heat Energy in the Soil of the Pannonian Basin in the Socialist Republic of Croatia. Proceedings of Solar energy meeting, IUC Dubrovnik, 1-12.

Jelić, K. and Kevrić, I. (1997): Plitka geotermalna energija u Hrvatskoj (Shallow Geothermal Energy in Croatia). 6. forum Hrvatskog energetskog društva, Zagreb, 1997, 181-190.

Jeon, J.S., Lee, S.R. and Kim, M.J. (2018): A modified mathematical model for spiral coil-type horizontal ground heat exchangers. Energy, 152, 732-743.

Kurevija, T. (2008): Analysis of potentials of shallow geothermal resources in heat pump systems in the city of Zagreb. Goriva i maziva, 47, 5, 373-390.
Kurevija, T. (2010): Energetsko vrednovanje plitkih geotermalnih potencijala Republike Hrvatske (Energetic evaluation of the shallow geothermal potential in the Republic of Croatia). Ph.D. thesis, University of Zagreb, Faculty of mining, geology and petroleum engineering.

Kurevija, T. and Vulin, D. (2010): Determining undisturbed ground temperature as part of shallow geothermal resources assessment. The Mining-Geology-Petroleum Engineering Bulletin (Rudarsko-geološko-naftni zbornik), 22, 1, 27-36.

Kurevija, T., Vulin, D. and Krapec, V. (2012): Effect of borehole array geometry and thermal interferences on geothermal heat pump system. Energy Conversion and Management, 60, 134-142.

Kurevija, T., Vulin, D., and Macenić, M. (2014): Impact of geothermal gradient on ground source heat pump system modeling The Mining-Geology-Petroleum Engineering Bulletin (Rudarsko-geološko-naftni zbornik), 28, 1, 39-45.

Kurevija, T., Macenić, M. and Borović, S. (2017): Impact of grout thermal conductivity on the long-term efficiency of the ground-source heat pump system. Sustainable Cities and Society, 31, 1-11.

Kurevija, T., and Strpić, K. (2018): Hydraulic and thermogeological design differences between two-loop vertical and inclined coaxial borehole heat exchangers. Renewable energy, 117, 314-323.

Kurevija, T., Macenić, M. and Strpić, K. (2018a): Steady-state heat rejection rates for a coaxial borehole heat exchanger during passive and active cooling determined with the novel step thermal response test method. The Mining-Geology-Petroleum Engineering Bulletin (Rudarsko-geološko-naftni zbornik), 33, 2, 61-71.

Kurevija, T., Strpić, K. and Koščak-Kolin, S. (2018b): Applying petroleum the pressure buildup well test procedure on thermal response test - A novel method for analyzing temperature recovery period. Energies, 11, 2, 366.

Lund, J. W. and Boyd, T. L. (2016): Direct utilization of geothermal energy 2015 worldwide review. Geothermics, 60, 66-93.

Malvić, T. (2016): Regional turbidites and turbiditic environments developed during Neogene and Quaternary in Croatia. Materials and Geoenvironment, 63, 1, 39-54.

Molavi, J. and McDaniel, J. (2016): A review of the benefits of geothermal heat pump systems in retail buildings. Procedia Engineering, 145, 1135-1143.

Narodne novine (NN) (2017): Pravilnik o jednostavnim i drugim građevinama i radovima (Ordinance on Simple and Other Buildings and Works). NN 112/17.

Pacchiega, C. and Fausti, P. (2017): A study on the energy performance of a ground source heat pump utilized in the refurbishment of an historical building: comparison of different design options. Energy Procedia, 133, 349-357.

Ruševljan, M., Soldo, V., Ćurko, T. (2009): Optimal Sizing of Borehole Heat Exchangers. Strojarstvo, 51, 5, 473-480.

Rybach, L. and Sanner, B. (2000): Ground source heat pump systems, the European experience. GHC Bulletin, 21, 1, 16-26. 
Sanner, B., Karytsas, C., Mendrinos, D. and Rybach, L. (2003): Current status of ground source heat pumps and underground thermal energy storage in Europe. Geothermics, 32, 4-6, 579-588.

Sarbu, I. and Sebarchievici, C. (2014): General review of ground-source heat pump systems for heating and cooling of buildings. Energy and buildings, 70, 441-454.

Soldo, V., Ruševljan, M. and Ćurko, T. (2009): Ispitna geotermalna dizalica topline sa sondom dubine 100 metara. In: Klima forum, Zadar.

Soldo, V., Ruševljan, M. (2010): Heat pump with 100 m borehole heat exchanger. Građenje \& Opremanje, 24, 31-35.

Soldo, V., Ruševljan, M., Ćurko, T. and Grozdek, M. (2010): Rezultati mjerenja na ispitnoj dizalici topline s bušotinskim izmjenjivačem topline. In: Zbornik radova 9. međunarodnog znanstveno-stručnog savjetovanja Energetska i procesna postrojenja i 4. međunarodnog foruma o obnovljivim izvorima energije.

Soldo, V., Ruševljan, M., Lepoša, L., Grozdek, M. and Ćurko, T. (2011): Prvo terensko mjerenje toplinskih svojstava tla u Hrvatskoj u svrhu projektiranja toplinskog sustava s dizalicom topline. In: Klima forum 2011. 3. forum o hlađenju, klimatizaciji i ventilaciji (pp. 72-72).

Soldo, V., Lepoša, L., Boban, L. and Borović, S. (2015): Implementation of the Distributed Thermal Response Test at Characteristic Geological Regions throughout Croatia. In: Proceedings of the World Geothermal Congress, 19-25 April, Melbourne, Australia.
Soldo, V., Borović, S., Lepoša, L. and Boban, L. (2016a): Comparison of different methods for ground thermal properties determination in a clastic sedimentary environment. Geothermics, 61, 1-11.

Soldo, V., Boban, L. and Borović, S. (2016b): Vertical distribution of shallow ground thermal properties in different geological settings in Croatia. Renewable energy, 99, 1202-1212.

Tinti, F., Giambastiani, B. and Mastrocicco, M. (2014): Types of Geo-exchanger Systems for Underground Heat Extraction. Chapter in Energy Vol. 9: Geothermal and Ocean Environment. Energy Science \& Tecnology, Studium Press LLC, USA.

Tinti, F., Pangallo, A., Berneschi, M., Tosoni, D., Rajver, D., Pestotnik, S., Jovanović, D., Rudinica, T., Jelisić, S., Zlokapa, B., Raimondi, A., Tollari, F., Zamagni, A., Chiavetta, C and Meggiolaro, M. (2016): How to boost shallow geothermal energy exploitation in the Adriatic area: the LEGEND project experience. Energy Policy, 92, 190-204.

Tinti, F., Barbaresi, A., Ferrari, M., Elkarmoty, M., Torreggiani, D., Tassinari, P. i Bonduà, S. (2017). Experimental calibration of underground heat transfer models under a winery building in a rural area. The Mining-Geology-Petroleum Engineering Bulletin (Rudarsko-geološko-naftni zbornik), 32, 3, 35-43.

\section{Internet sources:}

URL: http://geoera.eu/projects/muse/ (accessed 11th September 2018)

\section{SAŽETAK}

\section{Sustavni pregled istraživanja i iskorištavanja plitke geotermalne energije na području Hrvatske}

U nekoliko europskih država u znatnoj mjeri iskorištava se plitka geotermalna energija. Iako veći dio Republike Hrvatske pokazuje potencijal, iskorištavanje i instalacija samih sustava geotermalnih dizalica topline (dizalice topline i toplinski izmjenjivači) pokazuju lagani porast. S obzirom na navedeno u radu je dan kratak pregled dosad objavljenih istraživanja koja se odnose na iskorištavanje i procjenu potencijala plitke geotermalne energije u Hrvatskoj. Na području države trenutačno ne postoji agencija ili državni ured čija bi zadaća bila prikupljati i objavljivati podatke o instaliranim sustavima toplinskih izmjenjivača. Zbog toga je provedeno prikupljanje podataka, od kojih su neki dostupni u objavljenim znanstvenim radovima ili su skupljeni osobnim kontaktom, a koji se odnose na instalirane sustave izmjenjivača sa zatvorenim krugom. Na kraju je, prema skupljenim podatcima, dana procjena trenutačnoga stanja iskorištavanja plitke geotermalne energije za područje Republike Hrvatske.

\section{Ključne riječi:}

plitka geotermalna energija, Hrvatska, toplinski izmjenjivači

\section{Authors contribution}

Marija Macenić (mag. ing. min.) and Tomislav Kurevija (Assoc. Prof., PhD) initialized the idea. Marija Macenić reviewed scientific literature and wrote the paper. Tomislav Kurevija made the location map, calculated estimation of installed heating/cooling power and wrote the paper. Kristina Strpić (mag. ing. petrol.) gathered field data and compiled the utilization section. 